\title{
PRELIMINARY REMEDIAL ACTION OBJECTIVES FOR THE TANK 16 GROUNDWATER OPERABLE UNIT (U)
}

by W. C. Miles, Jr.

Westinghouse Savannah River Company Savannah River Site

Aiken, South Carolina 29808

Other Authors:
WSRC-TR- $-92-500$

DE93 008502

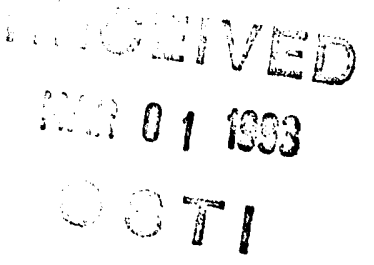

This paper was prepared in connection with work done under Contract No. DE-AC09-89SR18035 with the U. S. Department of Energy. By acceptance of this paper, the publisher and/or recipient acknowledges the U. S. Government's right to retain a nonexclusive, royalty-free license in and to any copyright covering this paper, along with the right to reproduce and to authorize others to reproduce all or part of the copyrighted paper. 


\section{DISCLAIMER}

This report was prepared as an account of work sponsored by an agency of the United States Government. Neither the United States Government nor any agency thereof, nor any of their employees, makes any warranty, express or implied, or assumes any legal liability or responsibility for the accuracy, completeness, or usefulness of any information, apparatus, product, or process disclosed, or represents that its use would not infringe privarely owned rights. Reference herein to any specific commercial product, process, or service by trade name, trademark, manufacturer, or otherwise does not necessarily constitute or imply its endorsement, recommendation, or favoring by the United States Government or any agency thereof. The views and opinions of authors expressed herein do not necessarily state or reflect those of the United States Government or any agency thereof.

This report has been reproduced directly from the best available copy.

Available to DOE and DOE contractors from the Office of Scientific and Technical Information, P.O. Box 62, Oak Ridge, TN 37831; prices available from (615) 576-8401, FTS 626-8401.

Available to the public from the National Technical Information Service, U.S. Deparment of Commerce, 5285 Port Royal Rd, Springfield, VA 22161. 


\title{
PRELIMINARY REMEDIAL ACTION OBJECTIVES
}

\author{
FOR THE
}

\section{TANK 16 GROUNDWATER OPERABLE UNIT (U)}

\author{
Unclassified
}

Author: W. C Miles, Jr.

Environmental Restoration Department

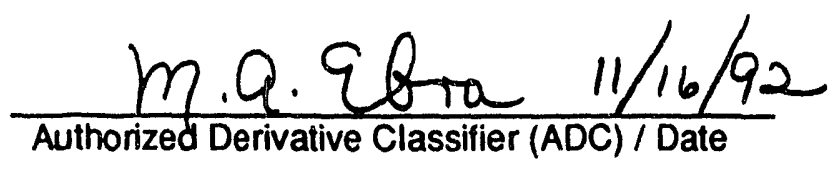

Westinghouse Savannah River Company

Savannah River Site Aiken, South Carolina 29803

Prepared for the U.S. Department of Energy under Contract No. De-AC09-89R18035 


\section{PRELIMHANARY REMEDIAL ACTION OBJECTIVES FOR THE TANK 16 GROUNDWATER OPERABLE UNIT \\ Westinghouse Savannah River Company Savannah River Site \\ Alken, South Carolina 29803}

\section{Table of Contents}

List of Tables.

List of Figures

3

Executive Summary

1.0 Purpose

5

2.0 Introduction

5

3.0 Media of Concern $\quad$......................................................................................... 7

4.0 Chemicals of Concern

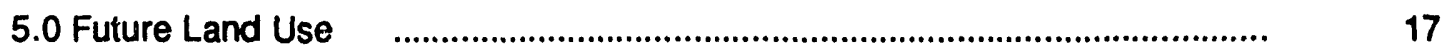

6.0 Applicable Or Relevant And Appropriate Requirements (ARARs) $\quad$............ 22

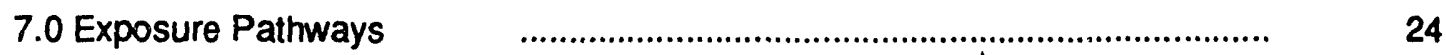

8.0 Preliminary Remedial Action Objectives $\quad$.................................................... 26

9.0 Preliminary General Response Actions $\quad$.................................................. 27

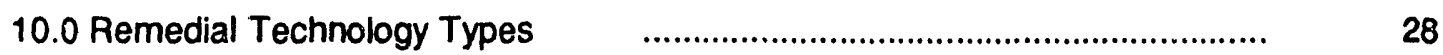

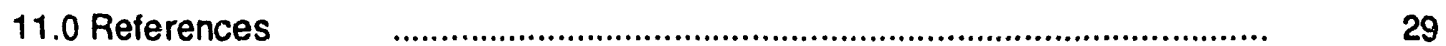




\section{List of Tables}

3.1 Tank 16 Radiochemical Content................................................................... 9

4.1 Chemical Composition Of H-Area High Activity Waste (aged $\sim 10$ years) …....... 12

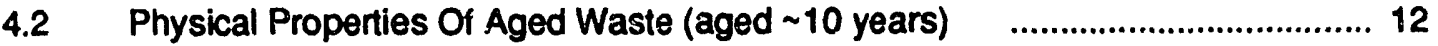

4.3 Low Concentration Nonradioactive Constituents Of $\mathrm{H}$-Area Supernate ........... 13

4.4. Radioactive Constituents Of H-Area Supernatant f..................................... 13

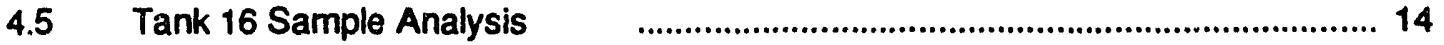

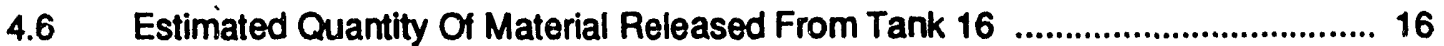

6.1.1 PDWS for the Tank 16 Primary Chemicals of Concern ..................................... 22

6.1.2 General Radionuclide Contaminant MCLs _............................................ 22

6.4.1 Maximum Permissible Concentrations In Air And Water For _....................... 23 Occupational Exposures Of Radionuclides ( $\mu \mathrm{Ci} / \mathrm{ml}$ )

\section{List of Flaures}

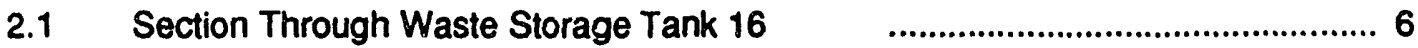

3.1 Local Groundwater Water Table Contour Map f................................................ 10

5.1 Map Of The Savannah River Site

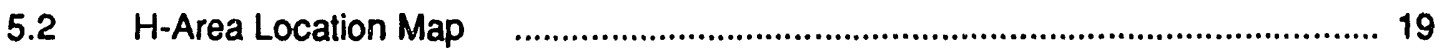

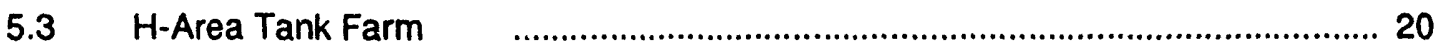

$5.4 \quad$ Tank 16 Features 


\section{EXECUTIVE SUMMARY}

Tank 16 is a High Level Radioactive Waste tank in the H-Area Tank Farm on the Savannah River Site that was placed into service in May 1959. A leak was detected in one of the construction weld joints while the tank was being filled. Before jet evacuation of the tank waste was completed, the leak overflowed the annulus pan and an estimated 16 to 700 gallons of waste escaped to the environment (soil and groundwater) over a six hour period contaminating approximately 1,600 70,000 cubic feet of soil with up to 5000 curies of activity (principally Cs ${ }^{137}$ ). The Tank 16 bottom is constructed below the groundwater table which resulted in almost immediate contamination of that medium. Low groundwater flow rates, the ion exchange property of adjacent soils, and the distance to the nearest surface water bodies $(1,500$ to 8,000 feet) indicates that surface water and sediment outcrop of contaminates may be expected between 44 and 530 years (Poe et al., 1974).

The Tank 16 structure (tank primary, tank annulus, and interior process equipment) is contaminated with high and low heat waste. Waste removal from Tank 16 was initiated in 1972 as a result of additional leakage. Only residual wastes, 75 gallons of water-insoluble waste containing 56,000 curies of activity in the tank primary (principally $\mathrm{Sr}^{90}$ ) and approximately 22,000 pounds of waste containing 30,000 curies of activity remain in the tank annulus (principally $\mathrm{Cs}^{137}$ ). Any liquids remaining at the time of waste removal have solidified leaving only solid wastes within the tank areas.

The H-Area Tank Farm is forecasted to remain operational for the next 30 years in support of the Separations Areas and the Defense Waste Processing Facility. Specific processes are planned for continued use in Savannah River Site support, such as; the In Tank Precipitation Facility, evaporators, and select tanks for feed and feed storage to the Defense Waste Processing Facility. Although decontamination and decommissioning activities may be initiated and completed over the next $\mathbf{3 0}$ years, government controlled access of the Savannah River Site is expected well beyond final closure.

The only applicable or relevant and appropriate requirements, ARARs, identified for the radionuclides ${ }^{90} \mathrm{Sr}$ and ${ }^{137} \mathrm{Cs}$, which are the primary chemicals of concern, and the groundwater medium were chemical-specific maximum contaminant levels (MCLs) from the Primary Drinking Water Regulations. No location or action-specific ARARs have been initially identified. However, to be considered (TBCs) ARARs, dealing with occupational exposure of radionuclides for air and water were identified.

Exposure pathways and receptors identified are primarily associated with $\mathrm{H}$-Area Tank Farm personnel contact with contaminated soils or groundwater during operational, maintenance, or potential decontamination and decommissioning activities. Potential exposure to the public and the environment is primarily limited to groundwater transport of contaminants.

Remedial action objectives consist of medium-specific and operable unit specific goals for protecting human health and the environment. These objectives are specific and do not limit the range of alternatives that may be developed. By development of these objectives prior to site characterization, remedial staff are provided long-term goals to use during analysis and selection of remedial technologies and alternatives resulting in a potential streamlining of the remedial alternative selection process. Goals for ingestion of groundwater and dermal exposure of groundwater to workers were developed.

A range of remedial technologies, which provides for treatment, containment, and removal requirements of contaminated media remaining at the Tank 16 groundwater operable unit, is identified and developed for each general response action. 


\begin{tabular}{|c|c|}
\hline $\begin{array}{l}\text { Prellminary RAOs for the Tank } 16 \text { Groundwater Operable Unit } \\
\text { Environmental Restoration Department } \\
\text { WSRC-TR-92-500 }\end{array}$ & $\begin{array}{l}\text { Revlsion: } 0 \\
\text { Date: } 10 / 28 / 92 \\
\text { Page } 5 \text { of } 30\end{array}$ \\
\hline
\end{tabular}

\subsection{PURPOSE}

The purpose of developing preliminary remedial action objectives (RAOS) is to provide the remedial staff with long-term goals to use during analysis and selection of remedial technologies and atternatives. Through early development of preliminary RAOs in the decision making process, the remedial staff may be able to streamline the consideration of remedial alternatives.

\subsection{INTRODUCTION}

Tank 16 is one of twenty-nine carbon steel High Level Radioactive Waste tanks in the H-Area Tank Farm used for processing of waste from the separation areas and located near the heart of the Savannah River Site (SRS). This tank was constructed in 1958-59 and placed into service in May 1959. Tank 16 is a "Type II" tank with a single carbon steel container sitting in a five foot annulus pan and encased in a concrete structure (see Figure 2.1). The tank is 27 feet high, 85 feet in diameter, and has a capacity of 1.03 million gallons.

Tank 16 is positioned in the southeastern corner of the old tank farm area within the Tank 13-16 quadraplex. The Tank 16 area is congested with overhead wires, surface structures, and subsurface pipelines. These structures are portions of the operational aspects of the H-Area Tank Farm.

In 1960, while the tank was being filled, a leak was detected in one of the construction weld joints. An annulus jet was prepared for cleaning the leak but prior to complete jet evacuation of the tank waste, the leak overflowed the annulus pan and escaped to the environment. Estimates are that 16 to 700 gallons of waste may have leaked to the soil over a six hour period before jetting was initiated and waste transferred from the Tank 16 annulus to Tank 14. During that time there was leakage of waste through the concrete encasement, probably along the construction joint in the concrete encasement. Up to 5000 curies, principally Cesium-137, may have been released.

The tank was refilled with low heat waste in 1968. The use of Tank 16 ceased after reoccurring leaks resumed in 1972. The supernate was transferred to Tank 13 and jetting was performed on accessible areas of the tank. (No waste leakage to the environment was identified.)

The Tank 16 groundwater operable unit is in the RFI/RI Program and is pending workplan approval by the USEPA and SCDHEC to perform groundwater characterization. 
FIGURE 2.1

SECTION THROUGH WASTE STORAGE TANK 16

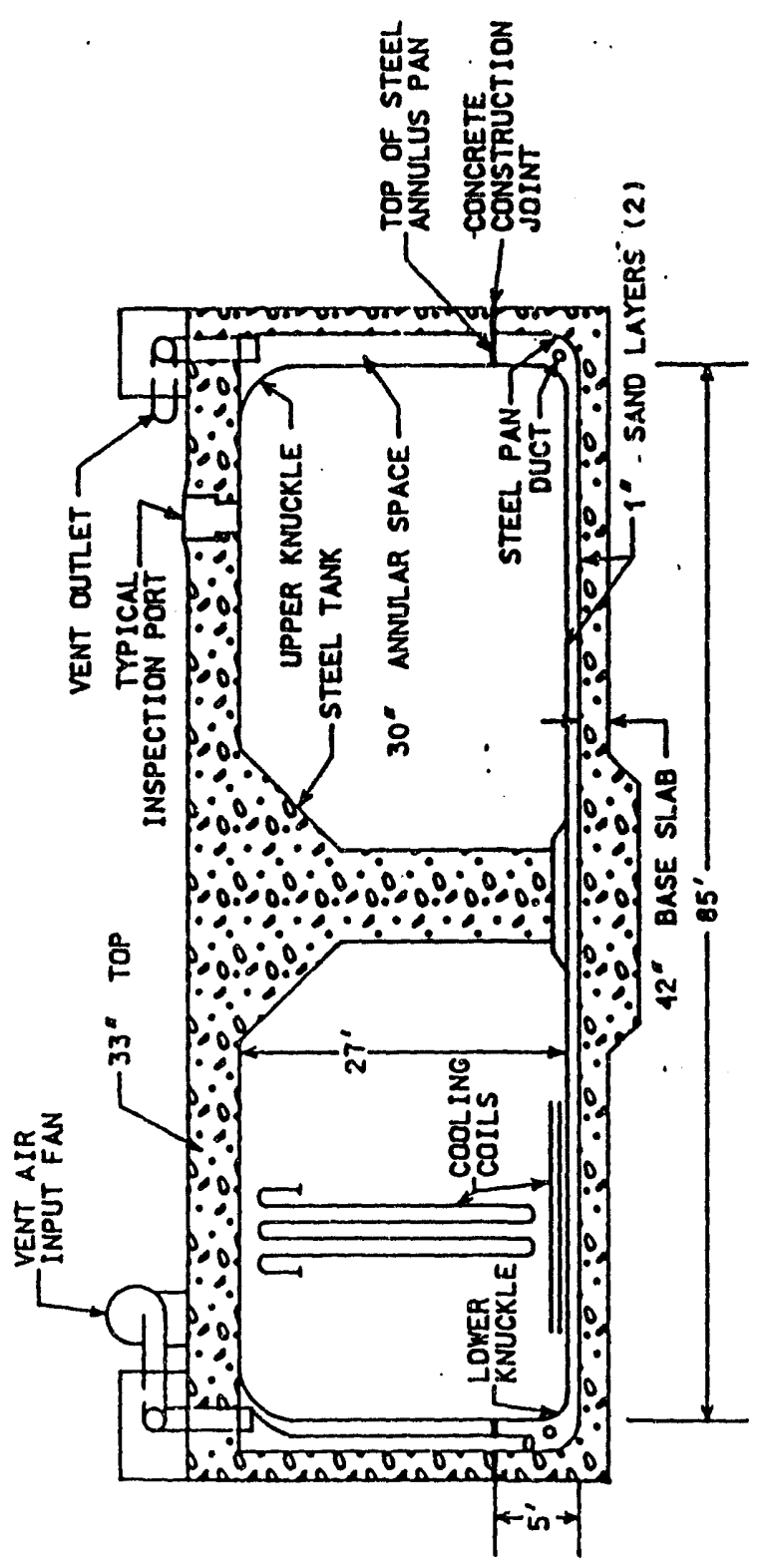

Modified from Poe et al. (1974). 


\subsection{MEDIA OF CONCERN}

The following media have been evaluated with regard to contaminants associated with the Tank 16 operable unit: groundwater, soil, surface water, sediment, air, structures, solid wastes, liquid wastes, and sludges. Each media that is either

-currently contaminated media to which individuals may be exposed or through which chemicals may be transported to potential receptors, or

- currently uncontaminated media that may become contaminated in the future due to contaminant transport has been described in the sections below. Since the focus of the development of these remedial action objectives is the groundwater operable unit, other media were evaluated based on its potential to become contaminated by the groundwater or serve as a source for continuing contamination of the groundwater medium.

Wetlands and biota (fiora/fauna) impacts will be addressed in future evaluations.

\subsection{GROUNDWATER}

Since the Tank 16 bottom is below the water table, any radioactivity that escaped from the concrete encasement reached the groundwater water table aquifer immediately. Due to the low flow rate of groundwater in this area and the ion exchange capabilities of the surrounding soil radioactivity migration is thought to be minimal.

Numerous monitoring wells and soil borings (proximal to Tank 16 and drilled to the top of the construction pad) constructed immediately after the release detected the presence of contaminants. Groundwater monitoring wells near Tank 16 have been used to track the release. Groundwater samples taken from a well installed next to Tank 16 showed the ratio of ${ }^{137} \mathrm{Cs}$ to ${ }^{134} \mathrm{Cs}$ to be 8 to 1 which is consistent with the calculated ${ }^{137} \mathrm{Cs} /{ }^{134} \mathrm{Cs}$ ratio for waste stored in Tank 16 (Poe et al., 1974). The potential of migration of contaminants into the lower aquifer (McBean) will be addressed in the implementation of the RFI/RI Work Plan for Tank 16.

\subsection{SOIL}

The Tank 16 leak to the environment was below grade and available data does not indicate any outcrop into surrounding surface soils. (Surface soils may have been contaminated by other non Tank 16 releases.) It is estimated that one gallon of Tank 16 waste would be equilibrated by ion exchange with approximately 100 cubic feet of soil comparable with that in the Tank 16 vicinity (Poe et al., 1974). On the basis of this equilibration ratio and the estimated waste release of $16-700$ gallons, approximately $1,600-70,000$ cubic feet $(60-2600$ cyds) of subsurface soils may have been contaminated.

\subsection{SURFACE WATER}

The Tank 16 leak to the environment was below grade and available data does not indicate any outcrop into surface water. The nearest surface water bodies are Upper Three Runs Creek which is approximately 8000 feet north of the H-Area Tank Farm, a tributary to Upper Three Runs Creek (McQueen Branch) which is 2500 feet east of Tank 16, a tributary to Upper Three Runs Creek (Crouch Branch) which is 2500 feet west of $\mathrm{H}$ Area (see Figure 3.1) and a tributary to Four Mile Creek which is 1500 feet southwest of Tank 16. Low groundwater flow rates and the ion exchange property of the Tank 16 adjacent soils indicate that surface water outcrop of contaminates originating from the Tank 16 leakage to the environment is estimated at between 44 and 530 years. (Poe et al., 1974.) 


\subsection{SEDIMENT}

The Tank 16 leak to the environment was below grade and available data does not indicate any outcrop into sediment. The nearest locations for sediment contamination are associated with Upper Three Runs Creek which is approximately 8000 feet north of the H-Area Tank Farm, a tributary to Upper Three Runs Creek (McQueen Branch) which is 2500 feet east of Tank 16, a tributary to Upper Three Runs Creek (Crouch Branch) which is 2500 feet west of H-Area (see Figure 3.1) and a tributary to Four Mile Branch which is 1500 feet southwest of Tank 16. Low groundwater flow rates and the ion exchange property of the Tank 16 adjacent soils indicate that sediment contamination originating from the Tank 16 leakage to the environment is estimated at between 44 and 530 years (Poe et al., 1974.).

\section{$3.5 \quad$ AIR}

The Tank 16 leak to the environment was below grade and available data does not indicate any outcrop in surrounding surface soils or sediments. Significant airborne releases could occur should excavation be performed in the subsurface soils surrounding Tank 16 and the H-Area Tank Farm. Should contaminants reach surface soils or sediment, airborne releases could occur as the result of wet/dry seasonal fluctuations.

\subsection{STRUCTURES}

The Tank 16 stristure is currently intact and managed by Waste Management. The tank, annulus, and interior process equipment are contaminated with high heat waste (HHW) and low heat wast (LHW). Waste was removed from the tank following reoccurring leaks in 1972. Jetting vias performed on accessible areas of the tank.

Any additional activities to remove resicual wastes could increase personnel exposure. Monitoring of Tank 16 will continue until decontamination and decommissioning (D\&D) activities are complete. Tank 16 is located within a designated Radiologically Controlled Area (RCA).

\subsection{SOLID WASTES}

Waste removal from Tank 16 was initiated in 1972 as a result of additional leakage. (No waste leakage to the environment was identified.) Only residual wastes were left in the tank and annulus areas. Any liquids remaining at the time of waste removal have solidified leaving only solid wastes within the tank and annulus areas. Subsequent remote observations of the Tank 16 primary and annulus have verified the solid nature of remaining tank waste.

Approximately 75 gallons of water-insoluble waste containing 56,000 curies (Ci) of activity remain in the tank primary (see Table 3.1 ). The insoluble waste is mainly ferrous oxalate. The activity in the tank primary is primarily $\mathrm{Sr}^{90}$.

An estimated 22,000 pounds of waste (natrodavyne and sand) containing 30,000 curies of activity remain in the tank annulus (see Table 3.1). The activity in the tank annulus is due primarily to $\mathrm{Cs}^{137}$.

Should groundwater infiltrate the tank area (the tank bottom was constructed below the water table), it is conceivable that solid waste in the primary tank and tank annulus could be resuspended and migrate to the environment. 


\section{$3.8 \quad$ LIQUID WASTES}

No liquid wastes are present in Tank 16 or its annulus. Any liquids remaining at the time of waste removal have solidified leaving only solid wastes within the tank and annulus areas. Subsequent remote observations of the Tank 16 primary and annulus have verified the solid nature of remaining tank waste.

\subsection{SLUDGES}

Although initial Tank 16 wastes were characterized as sludge and supernatant, all sludges have solidified since the last waste removal in 1972. Subsequent remote observations of the Tank 16 primary and annulus have verified the solid nature of remaining tank waste.

TABLE 3.1

TANK 16 RADIOCHEMICAL CONTENT

\begin{tabular}{|c|c|c|c|}
\hline & \multicolumn{2}{|c|}{ Activity Concentration (mCi/g) Activity (Ci) } & \\
\hline \multicolumn{4}{|l|}{ Primary } \\
\hline $90 \mathrm{Sr}$ & 87.0000 & $56,000.000$ & \\
\hline$\sqrt{37} \mathrm{Cs}$ & 0.0040 & 2.600 & 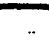 \\
\hline $238,239 \mathrm{Pu}$ & 0.0006 & 0.400 & \\
\hline \multicolumn{4}{|l|}{ Annulus } \\
\hline$\sqrt{37} \mathrm{Cs}^{*}$ & 43.0000 & $30,000.000$ & \\
\hline
\end{tabular}

- Concentration calculated based on 22,000 lbs. of insoluble solids containing 30,000 curies.

Modified from Abel et al. (1987). 
Preliminary RAOs for the Tank 16 Groundwater Operable Unif

Environmental Restoration Department

WSRC-TR-92-500
Revision: 0

Date: 10/28/92

Page 10 of 30

FIGURE 3.1

LOCAL WATER TABLE CONTOUR MAP

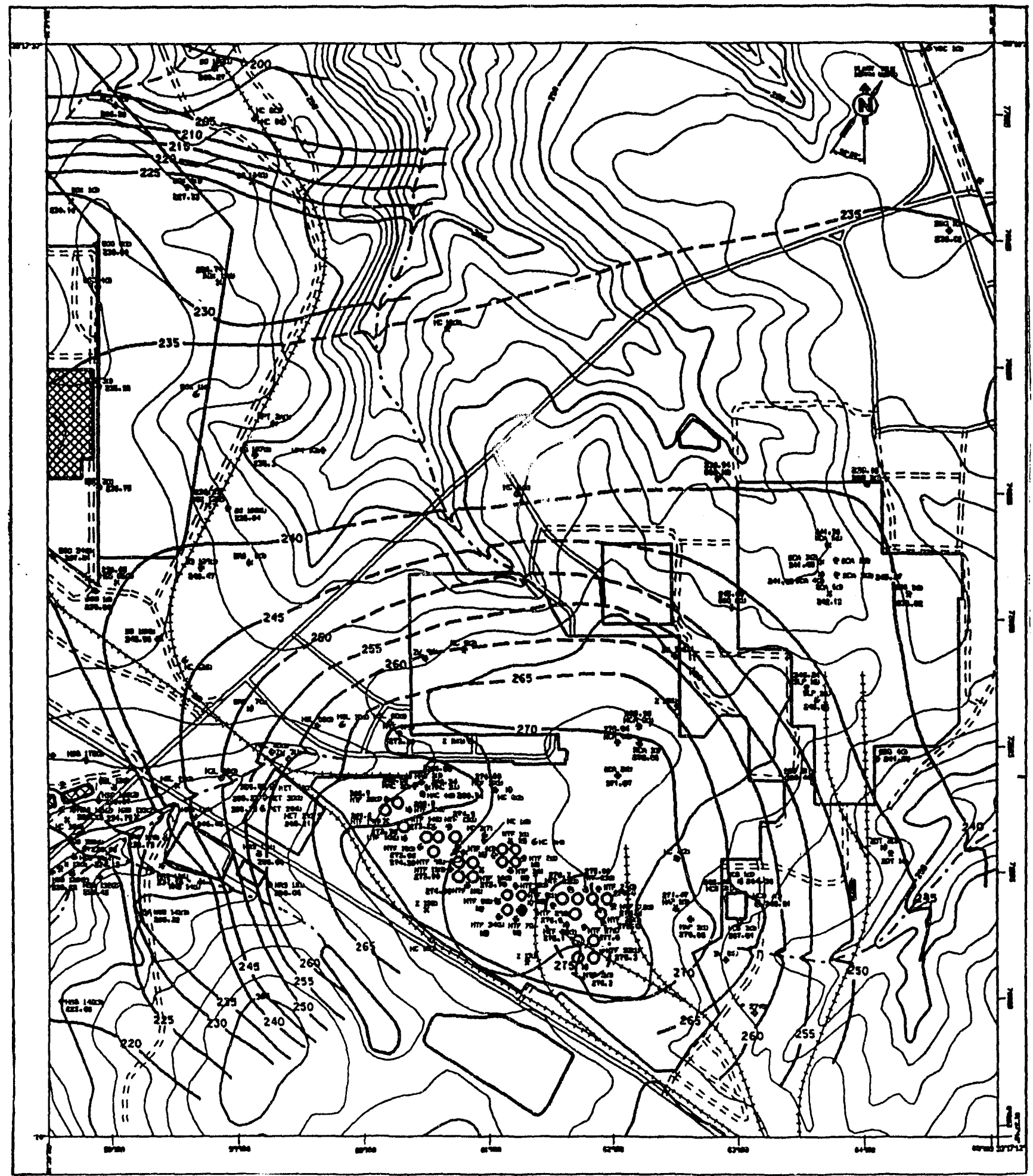

First Quarter Calendar Year 1992 Groundwater Data. 
Assuming the waste relitased was primarily composed of constituents observed in a sample of Tank 16 supernate (see Table 4.5) and those expected to be present by Poe et al. (1974), the ranges of contaminate quantities (including nonradioactive substances) that may have been released are listed in Table 4.6.

Of the radionuclides presemt in the waste tl.at leaked into the soil, ${ }^{137} \mathrm{Cs}$ is in the largest quantity and has the largest biological hazard. The ${ }^{90} \mathrm{Sr}$ concentration is relatively low (currently $0 \mathrm{n84}$ $\mathrm{Ci} / \mathrm{gal})$ but should be considered. ${ }^{95} \mathrm{Zr}-95 \mathrm{Nb},{ }^{103} \mathrm{Ru}$, and ${ }^{106} \mathrm{Ru}$ were present in low concentrations at the time of the leak, and due to their relatively short half lives have been calculated to have decayed to less than $1 \times 10^{-9} \mathrm{Ci} g a l$ in the thirty-two years since the leak.

Although H-Area Tank Farm waste and specific waste sample analysis from Tank 16 indicate potential contamination by non-hazardous/non-radioactive and hazardous/non-radioactive constituents, the primary chemicals of concem in development of remedial action obje are the radioactive constituents ${ }^{137} \mathrm{Cs}$ and ${ }^{90} \mathrm{Sr}$.

TABLE 4.1

CHEMICAL COMPOSITION OF H-AREA HIGH ACTIVITY WASTE (aged $\sim 10$ years)

\begin{tabular}{|c|c|c|}
\hline & Constituent & Concentration \\
\hline \multicolumn{3}{|l|}{ Supemate } \\
\hline & $\mathrm{NaNO}_{3}, \mathrm{NaNO}_{2}$ & $4-5 M$ \\
\hline & $\mathrm{Na}_{2} \mathrm{CO}_{3}$ & $0.1 \mathrm{M}$ \\
\hline & $\mathrm{Na}_{2} \mathrm{SO}_{4}$ & $0.05-0.1 \mathrm{M}$ \\
\hline & $\mathrm{NaAlO}_{2}$ & $0.5-1 M$ \\
\hline & $\mathrm{NaOH}$ & $1-1.5 \mathrm{M}$ \\
\hline & $137 \mathrm{Cs}$ & $1-20 \mathrm{CV} / \mathrm{gal}$ \\
\hline \multicolumn{3}{|l|}{ Sludge } \\
\hline & $\mathrm{Fe}(\mathrm{OH})_{3}, \mathrm{MnO}_{2}, \mathrm{~A}(\mathrm{OH})_{3}$ & Settled Volume $5-8 \%$ of supernate volume \\
\hline & $90 \mathrm{Sr}$ & $10-500 \mathrm{Ci} / \mathrm{gal}$ \\
\hline & $239 \mathrm{Pu}$ & $3-30 \times 10^{-3}$ Cigal \\
\hline & $238 \mathrm{Pu}$ & $2 \times 10^{-1}$ Civgal \\
\hline
\end{tabular}

From Poe et al. (1974).

TABLE 4.2

PHYSICAL PROPERTIES OF AGED WASTE (aged $\sim 10$ years)

\begin{tabular}{|c|c|c|}
\hline \multicolumn{3}{|l|}{ Supernate } \\
\hline & Specific Gravity & $1.2-1.4$ \\
\hline & Viscosity & $\sim 2 \mathrm{CP}$ \\
\hline & Heat Generation, \% of total (Practically all from cesium) & 50 \\
\hline \multicolumn{3}{|c|}{ 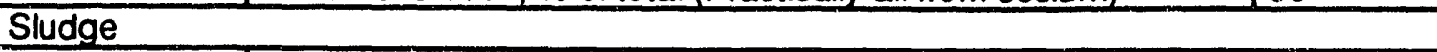 } \\
\hline & Specific Gravity & $1.5-1.8$ \\
\hline & Viscosity & Very High \\
\hline & Heat Generation, \% of total (Practically all from strontium) & 50 \\
\hline
\end{tabular}

From Poe et al. (1974). 
Prellminary RAOs for the Tank 16 Groundwater Operable Unlt

Revision: 0

Environmental Restoration Department

Date: 10/28/92

WSRC-TR-92-500

Page 13 of 30

TABLE 4.3

LOW CONCENTRATION

NONRADIOACTIVE CONSTITUENTS OF H-AREA SUPERNATE (coolẹd $\sim 5$ years)

\begin{tabular}{|c|c|}
\hline Constituest & Concentration \\
\hline $\mathrm{CO}_{3}^{-2}$ & $<0.1-0.3 \mathrm{M}$ \\
\hline $\mathrm{SO}_{4}^{-2}$ & $0.02-0.08 \mathrm{M}$ \\
\hline $\mathrm{PO}_{4}^{-3}$ & $<0.01-0.05 \mathrm{M}$ \\
\hline $\mathrm{Cl}^{-}$ & $0.005-0.029 M$ \\
\hline $\mathrm{CrO}_{4}^{-2}$ & $0.001-0.005 \mathrm{M}$ \\
\hline$F^{*}$ & $0.001-0.004 \mathrm{M}$ \\
\hline $\mathrm{Fe}$ & $6 \times 10^{-5}-0.2 \mathrm{M}$ \\
\hline $\mathrm{Hg}$ & $60-340 \mu \mathrm{g} / \mathrm{ml}$ \\
\hline $\mathrm{NH}_{4}^{+}$ & $<1-67 \mu \mathrm{g} / \mathrm{ml}$ \\
\hline $\mathrm{Ag}$ & $0.1 .4 \mu \mathrm{g} / \mathrm{ml}$ \\
\hline $\mathrm{Pb}$ & $2.58 \mu \mathrm{g} / \mathrm{ml}$ \\
\hline U & $0.4-6 \mu \mathrm{g} / \mathrm{ml}$ \\
\hline Reducing normalities & $<0.01-0.3 \mathrm{~N}$ \\
\hline
\end{tabular}

From Poe et al. (1974).

TABLE 4.4

RADIOACTIVE CONSTITUENTS OF H-AREA SUPERNATANT (cooled $\sim 5$ years)

\begin{tabular}{|c|c|}
\hline Constituent & Concentration, $\mu \mathrm{Ci} / \mathrm{gal}$ \\
\hline${ }^{60} \mathrm{Co}$ & $<3-12$ \\
\hline${ }^{89} \mathrm{Sr}$ & $<0.3-<35$ \\
\hline $90 \mathrm{Sr}$ & $30-3,600$ \\
\hline $95 \mathrm{Zr}$ & $<5-<10$ \\
\hline $95 \mathrm{Nb}$ & $<1-2$ \\
\hline${ }^{103} \mathrm{Ru}$ & $<2-4,900$ \\
\hline${ }^{106} \mathrm{Ru}$ & $1,500-6,800$ \\
\hline${ }^{134} \mathrm{Cs}$ & $100,000-170,000$ \\
\hline $137 \mathrm{Cs}$ & $1,000,000-20,000,000$ \\
\hline $141 \mathrm{Ce}$ & $<1-<44$ \\
\hline${ }^{144} \mathrm{Ce}$ & $<8-<440$ \\
\hline${ }^{154} \mathrm{Eu}$ & $<3-5$ \\
\hline $\mathrm{Pu}$ & $0.01-4$ \\
\hline $24 \sqrt{A m}$ & $<1-4$ \\
\hline${ }^{3} \mathrm{H}$ (tritium) & -75 \\
\hline
\end{tabular}

From Poe et al. (1974). 
Preliminary RAOs for the Tank 16 Groundwater Operable Unit Environmental Restoration Department

Revision: 0

TABLE 4.5

TANK 16 SAMPLE ANALYSIS

\begin{tabular}{|c|c|c|c|c|}
\hline Date Reported & $5 / 60$ & $5 / 60$ & $9 / 60$ & $4 / 65$ \\
\hline $\begin{array}{l}\text { Description of } \\
\text { Sample }\end{array}$ & Supemate & Sludge & Annulus & Supernate \\
\hline Date Sampled & $5 / 25 / 60$ & $5 / 25 / 60$ & $9 / 17 / 60$ & $3 / 30 / 65$ \\
\hline Total Solids & 45.5 wt. $\%$ & 50.3 wt. \% & 42 wt. $\%$ & 31.28 wt. \% \\
\hline Specific Gravity & 1.37 & & 1.36 & 1.385 \\
\hline $\mathrm{pH}$ & $>11$ & $>11$ & $>11$ & $11.7-12.3$ \\
\hline $\mathrm{NaNO}_{3}$ & & & & 4.74 wt. $\%$ \\
\hline $\mathrm{NaOH}$ & & & & $5.80 w t . \%$ \\
\hline $\mathrm{NaAlO}_{3}$ & $\sqrt{64.8 \mathrm{~g} / 1}$ & $300 \mathrm{~g} / 1$ & & 0.44 wt. \% \\
\hline$\overline{\mathrm{Na}_{2} \mathrm{CO}_{3}}$ & & & & $0.39 w t . \%$ \\
\hline $\mathrm{Na}_{2} \mathrm{SO}_{4}$ & & & & 0.75 wt. $\%$ \\
\hline U & $2.4 \times 10^{-3} \mathrm{~g} /$ & $1.1 \times 10^{-3 / 1}$ & & \\
\hline $\mathrm{Cl}^{-}$ & $0.6 \mathrm{~g} / \mathrm{l}$ & & & $29 \mathrm{ppm}$ \\
\hline $\mathrm{PO}_{4}^{-3}$ & & & & $<0.02 \mathrm{~g} / 1$ \\
\hline $\mathrm{Fe}^{+3}$ & & & & $0.011 \mathrm{~g} / 1$ \\
\hline Al & $25.5 \mathrm{~g} / 1$ & & & \\
\hline Gross Alpha/2 & $7641 n^{3}$ & $21 \times 10^{4}$ & $5=10^{3}$ & $000 \times 13$ \\
\hline Pu Alpha'/2 & $\frac{7.6 \times 10^{0}}{8.7 \times 10^{3}}$ & $\frac{3.4 \times 10^{4}}{3.2 \times 10^{4}}$ & $5.2 \times 10^{0}$ & $\frac{3.23 \times 10^{0}}{1.71 \times 10^{3}}$ \\
\hline 241 Am Alpha ${ }^{/ 2}$ & $<2.5 \times 10^{3}$ & 500 & & \\
\hline $237 \mathrm{No} \mathrm{Alpha}^{12}$ & 22 & 16.6 & & \\
\hline Gross Beta $^{13}$ & $1.6 \times 10^{8}$ & $2.5 \times 10^{7}$ & $2.1 \times 10^{8}$ & $1.45 \times 10^{8}$ \\
\hline Gross Gamma $^{13}$ & $1.1 \times 10^{8}$ & $1.3 \times 10^{6}$ & $1.2 \times 10^{8}$ & $6.97 \times 10^{7}$ \\
\hline $95 \mathrm{Zr}-\mathrm{Nb}^{/ 3}$ & $8.6 \times 10^{6}$ & $5.8 \times 10^{5}$ & . & \\
\hline $90 \mathrm{Sr}^{3}$ & $4.4 \times 10^{6}$ & $1.3 \times 10^{6}$ & & $4.63 \times 10^{5}$ \\
\hline${ }^{144} \mathrm{Ce}^{13}$ & $1.1 \times 10^{5}$ & 460 & & \\
\hline $103,106 \mathrm{Ru}^{13}$ & $4.5 \times 10^{6}$ & $2.7 \times 10^{5}$ & & \\
\hline $137 \mathrm{Cs}^{13}$ & $8.0 \times 10^{7}$ & $3.9 \times 10^{5}$ & & $6.67 \times 10^{7}$ \\
\hline
\end{tabular}


PrelimInary RAOs for the Tank 16 Groundwater Operable Unit

TABLE 4.5 (continued)

TANK 16 SAMPLE ANALYSIS

\begin{tabular}{|c|c|c|c|c|c|c|c|}
\hline \multicolumn{2}{|c|}{ Date Reported } & \multicolumn{2}{|c|}{$3 / 72$} & \multicolumn{2}{|c|}{$3 / 72$} & \multicolumn{2}{|c|}{$3 / 72$} \\
\hline \multicolumn{2}{|c|}{ Description of Sample } & \multicolumn{2}{|c|}{$\begin{array}{l}\text { Salt From Top of Crust } \\
\text { on Annulus Floor }\end{array}$} & \multicolumn{2}{|c|}{$\begin{array}{l}\text { Sall From Edge of } \\
\text { Annulus Pan Ledge }\end{array}$} & \multicolumn{2}{|c|}{$\begin{array}{l}\text { Salt From Top of } \\
\text { Annulus Pan Ledge }\end{array}$} \\
\hline \multicolumn{2}{|c|}{ Water Solubility, wt \% } & \multicolumn{2}{|c|}{82} & \multicolumn{2}{|c|}{99} & \multicolumn{2}{|c|}{99} \\
\hline \multicolumn{2}{|l|}{ Cations } & Soluble & Insoluble & Soluble & Insoluble & Soluble & Insoluble \\
\hline \multirow{2}{*}{\multicolumn{2}{|c|}{ Major (10-100\%) }} & $\mathrm{Na}$ & Al & $\mathrm{Na}$ & Al & $\mathrm{Na}$ & \\
\hline & & & $\mathrm{Ca}$ & & $\mathrm{Ca}$ & & \\
\hline \multirow{5}{*}{\multicolumn{2}{|c|}{ Minor (1-10\%) }} & $\mathrm{Cr}$ & & & $\mathrm{Cr}$ & & \\
\hline & & & & & $\mathrm{Ca}$ & $\overline{S i}$ & \\
\hline & & & & $\overline{\mathbf{A}}$ & $\mathrm{Cd}$ & & \\
\hline & & & & & $F_{\theta}$ & & \\
\hline & & & & & $\mathrm{Ni}$ & & \\
\hline \multirow{5}{*}{\multicolumn{2}{|c|}{ Trace $(0.1-1 \%)$}} & Al & & $\mathrm{Ca}$ & $\mathrm{Mg}$ & $\mathrm{Li}$ & \\
\hline & & $\mathrm{ca}$ & & $\overline{C d}$ & $\mathrm{~Pb}$ & Mo & \\
\hline & & & & $\overline{F \theta}$ & & $\overline{\mathrm{Pb}}$ & \\
\hline & & & & Si & & & \\
\hline & & & & $\overline{C r}$ & & & \\
\hline \multirow{2}{*}{\multicolumn{2}{|c|}{ Faint Trace $(0.01-1 \%)$}} & $\mathrm{Mg}$ & & Mg & $\mathrm{Cu}$ & $\mathrm{Ca}$ & \\
\hline & & & & & $M n$ & $\mathrm{Mg}$ & \\
\hline \multirow[t]{4}{*}{ Anions, \% } & $\mathrm{NO}_{3}$ & 34 & & 45 & & 38 & \\
\hline & $\mathrm{OH}$ & 0 & & 1.7 & & 0.1 & \\
\hline & $\mathrm{SO}_{4}$ & 0.1 & & 0.7 & $\div$ & 0.8 & \\
\hline & $\mathrm{CO}_{3}$ & 0.6 & & 3.2 & & $\overline{0.5}$ & \\
\hline \multicolumn{2}{|c|}{ Radiation, R/hr } & 2 & & 0.3 & & 0.1 & \\
\hline \multirow{2}{*}{\multicolumn{2}{|c|}{\begin{tabular}{|l|}
$137 \mathrm{Cs}, \mathrm{d} / \mathrm{m} / \mathrm{g}$ \\
${ }^{134} \mathrm{Cs}, \mathrm{d} / \mathrm{m}^{\prime} \mathrm{q}^{*}$
\end{tabular}}} & $1.5 \times 10^{9}$ & & $8.3 \times 10^{8}$ & & $4.5 \times 10^{8}$ & \\
\hline & & $2.5 \times 10^{8}$ & & $5.5 \times 10^{6}$ & & $3.7 \times 10^{6}$ & \\
\hline \multicolumn{2}{|c|}{${ }^{137} \mathrm{Cs} /{ }^{134} \mathrm{Cs}$ Ratio } & 6 & & 151 & & 122 & \\
\hline \multicolumn{2}{|c|}{$\begin{array}{l}\text { Age, Years (Assuming } \\
x \text { yrs. at }{ }^{137} \mathrm{Cs} /{ }^{134} \mathrm{Cs} \\
\text { Ratio }=6 \text { ) }\end{array}$} & $x$ & & $x+10.6$ & & $x+9.9$ & \\
\hline
\end{tabular}

- Reference document has ${ }^{137} \mathrm{Cs}, \mathrm{d} / \mathrm{m} / \mathrm{g}$ which is clearly a typographical error. Note: Absence of values indicates data not reported in source document.

From Davis et al. (1977) 
Prellminary RAOs for the Tank 16 Groundwater Operable Unlt

Reviston: 0

Environmental Restoration Department

Date: 10/28/92

WSRC-TR-92-500

Page 16 of 30

TABLE 4.6

ESTIMATED QUANTITY OF MATERIAL RELEASED FROM TANK 16

\begin{tabular}{|l|l|l|}
\hline Waste & $\begin{array}{l}\text { Minimum } \\
16 \text { gallons }\end{array}$ & $\begin{array}{l}\text { Maximum } \\
700 \text { gallons }\end{array}$ \\
\hline \hline Chromium & 1 gram (g) & 300 grams (g) \\
\hline Mercury & $4 \mathrm{~g}$ & $900 \mathrm{~g}$ \\
\hline Lead & $0.1 \mathrm{~g}$ & $150 \mathrm{~g}$ \\
\hline Silver & $0.01 \mathrm{~g}$ & $10 \mathrm{~g}$ \\
\hline $137 \mathrm{Cs}$ & $16 \mathrm{Curies}(\mathrm{Ci})$ & $14000 \mathrm{Curies}(\mathrm{Ci})$ \\
\hline 90 Sr & $0.001 \mathrm{Ci}$ & $2 \mathrm{Ci}$ \\
\hline Other beta-gamma & $2 \mathrm{Ci}$ & $130 \mathrm{Ci}$ \\
\hline Alpha & $<0.0001 \mathrm{Ci}$ & $0.2 \mathrm{Ci}$ \\
\hline Tritium & $0.0001 \mathrm{Ci}$ & $0.05 \mathrm{Ci}$ \\
\hline
\end{tabular}

From RFI/RI Workplan for Tank 16 (1991). 


\subsection{EUTURELLAND USE}

The Tank 16 operable unit is located within the H-Area Tank Farm which is located near the heart of the Savannah River Site (see Figure.5.1). The H-Area Tank I arm (see Figure 5.2) is an operational facility which contains twenty-nine tanks used for processing of waste from the separation areas. The H-Area Tank Farm is divided into two distinct areas, the old hill and the new hill.

Tank 16 is positioned in the southeastem corner of the old tank farm area within the Tank 13-16 quadraplex (see Figure 5.3). The Tank 16 area is congested with overhead wires, surface structures, and subsurface pipelines. These structures are portions of the operational aspects of the H-Area Tank Farm (see Figure 5.4).

The Tank Farm will continue to provide operational support to other facilities. The H-Area Tank Farm is forecasted to remain operational for the next 30 years in support of the Separations and the Defense Waste Processing Facility (DWPF). Specific processes are planned for continued use in SRS support, such as, the In Tank Precipitation Facility (ITP), evaporators, and select tanks for feed and feed storage to the DWPF. 
FIGURE 5.1

MAP OF THE SAVANNAH RIVER SITE

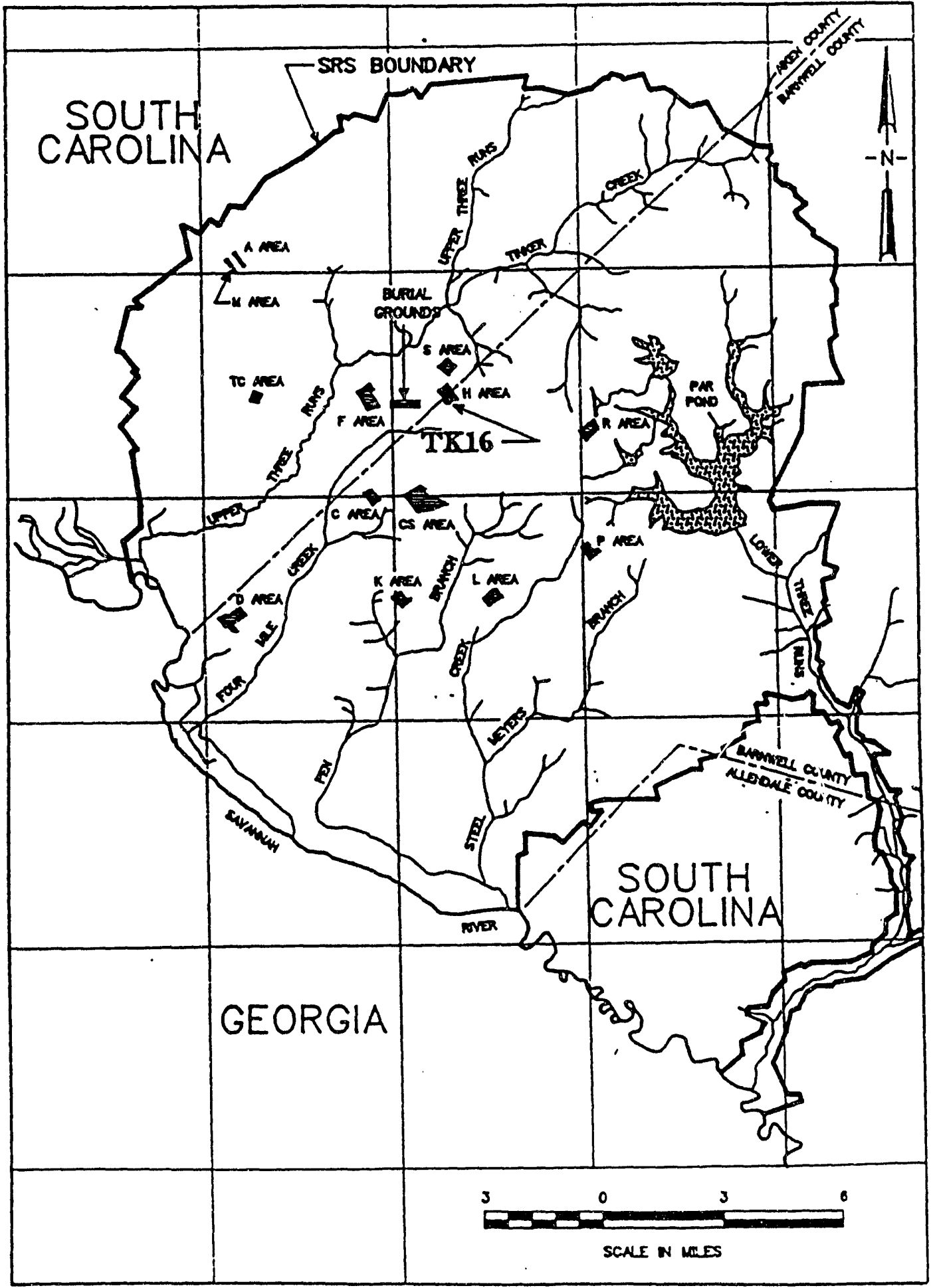

Modified from RFI/RI Work Plan for Tank 16 (1991). 
FIGURE 5.2

\section{H-AREA LOCATION MAP}

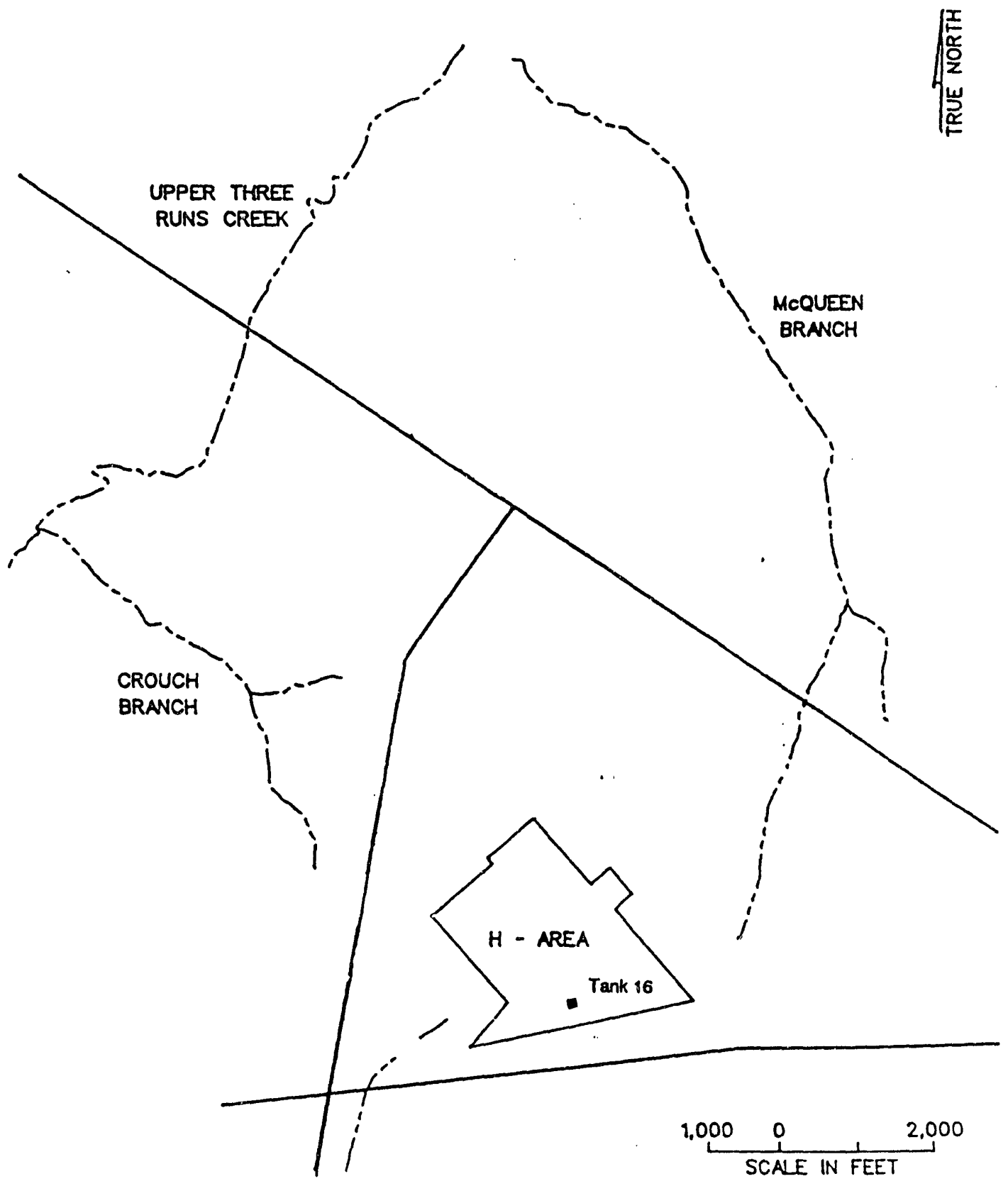

Modified from RFI/RI Work Plan for Tank 16 (1991). 


\section{FIGURE 5.3}

H-AREA TANK FARM

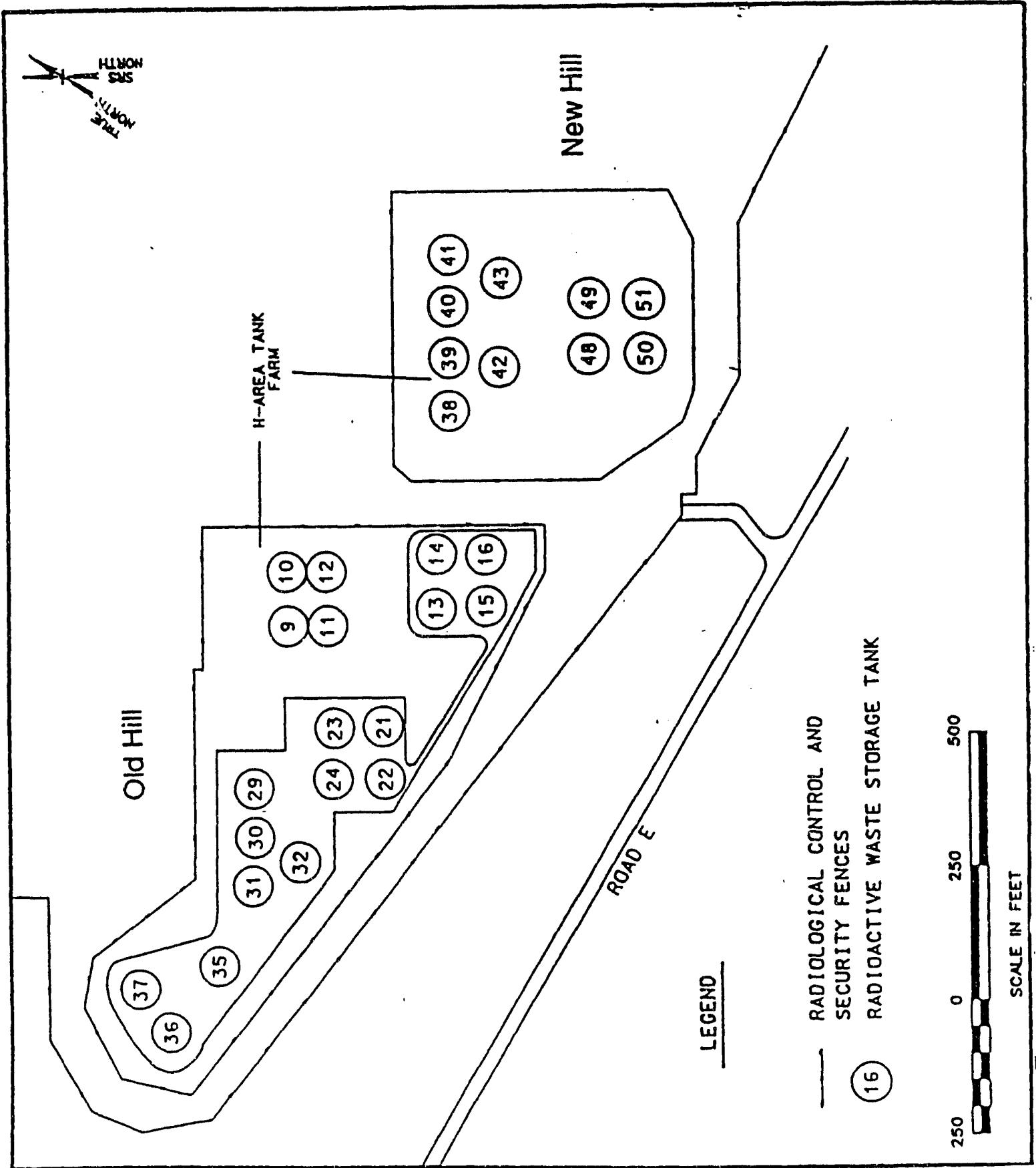

Modified from RFI/RI Work Plan for Tank 16 (1991). 
FIGURE 5.4

TANK 16 FEATURES

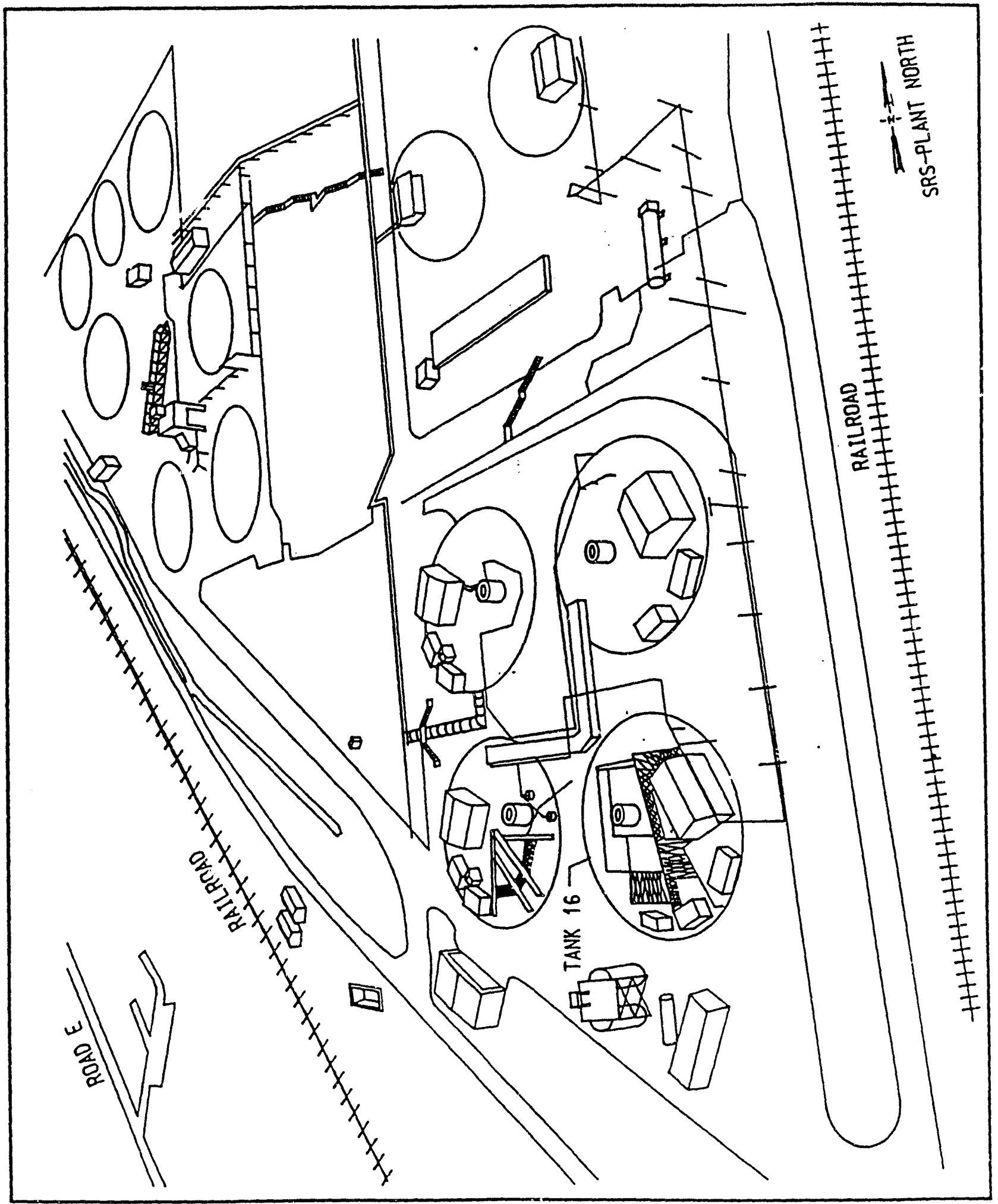

From RFI/RI Work Plan for Tank 16 (1991). 


\subsection{APPLICABLE OR RELEVANT AND APPROPRIATE REQUIIEMENTS}

Applicable or relevant and appropriate requirements (ARARs) may be subdivided into three types: chemical-specific, location-spe sific, and action-specific. Chemical-specific ARARs are usually health or risk based numbers or methodologies which result in the establishment of numerical values (e.g., concentrations in a given medium). Location-specific ARARs are restrictions placed upon the concentration of a hazardous substances or conduct of activities solely because they are in special locations (e.g., wetlands). Action-specific ARARs are usually technology or activity based requirements or limitations on actions taken with respect to hazardous wastes.

To be considered (TBCs) ARARs are requirements that include nonpromulgated criteria, advisories, guidance, and proposed standards issued by Federal and State governments. TBCs should be considered to determine preliminary remediation goals when no ARARs exist for particular contaminants.

\subsection{CHEMICAL-SPECIFIC ARARS}

Chemical-specific ARARs (Primary Drinking Water Standards, PDWS) for the Tank 16 groundwater operable unit primary chemicals of concern ( ${ }^{137} \mathrm{Cs}$ and ${ }^{90} \mathrm{Sr}$ ) have been identified in Table 6.1.1. ( ${ }^{134} \mathrm{Cs}$ has also been identified.) General radionuclide maximum contaminant levels (MCLs) have been identified in Table 6.1.2. Occupational exposure guidelines have been identified as TBCs.

TABLE 6.1.1

PDWS ${ }^{a}$ FOR THE TANK 16 PRIMARY CHEMICALS OF CONCERN

\begin{tabular}{||c|c|c|c|c|}
\hline Analyte & Unit & Level & Status & Reference \\
\hline \hline Cesium-137 & pCil & $2 E+02$ & Final & EPA,1977 \\
\hline Cesium-134 & pCil & $8.13 E+01^{6}$ & Proposed & EPA,1977 \\
\hline Strontium-90 & pCi & $8 E+00^{C}$ & Final & CFR,1991 \\
\hline
\end{tabular}

a Drinking water standards set by EPA (1977) correspond to the level at which each radionuclide contributes $4 \mathrm{mrem} / \mathrm{yr}$ dose to an individual consuming 2 liters of contaminated liquid a day.

b The proposed standard is used because it is a lower value; final PDWS in 1977 may have been in error.

c Critical organ is bone marrow.

TABLE 6.1.2

GENERAL RADIONUCLIDE CONTAMINANT MCLS

\begin{tabular}{|c||c|c|c|c|c|}
\hline Constituent & Current MCL & Eff. Date & Proposed MCL & Publ. Date & Citation \\
\hline \hline $\begin{array}{c}\text { Adjusted Gross Alpha } \\
\text { (AGA) Emitters (including } \\
\text { Ra226/excluding Rn \& U) }\end{array}$ & $15 \mathrm{pCi} / \mathrm{L}$ & $7 / 24 / 77$ & & & $41 \mathrm{FR} 28404$ \\
\hline $\begin{array}{c}\text { Adjusted Gross Alpha } \\
\text { (AGA) Emitters(excluding } \\
\text { U, Ra226, Rn 222 }\end{array}$ & & & $15 \mathrm{pCi} / \mathrm{L}$ & $7 / 18 / 91$ & $56 \mathrm{FR} 33050$ \\
\hline $\begin{array}{c}\text { Beta Particle \& Photon } \\
\text { Emitters }\end{array}$ & $4 \mathrm{mrem} / \mathrm{yr}$ & $7 / 24 / 77$ & & & $41 \mathrm{FR} 28404$ \\
\hline $\begin{array}{c}\text { Beta Particle \& Photon } \\
\text { Emitters (exclud. Ra228) }\end{array}$ & & & 4 mrem ede/yr & $7 / 18 / 91$ & $56 \mathrm{FR33050}$ \\
\hline
\end{tabular}

a Proposed National Primary Drinking Water Regulations (NPDWR) for radionuclides are projected to become final $4 / 93$.

b The term "mrem ede/yr" refers to the dose committed over a period of 50 years to reference man from an annual intake at a rate of 2 liters of drinking water per day. 


\subsection{LOCATION-SPECIFIC ARARS}

No location-specific ARARs for the Tank 16 location have been identified at this time.

\subsection{ACTION-SPECIFIC ARARS}

No action-specific ARARs for the Tank 16 groundwater operable unit have been identified since technology identification and evaluation is in its initial phase.

\subsection{TO BE CONSIDERED}

Occupational exposure guidelines have been identified as TBCs for the Tank 16 operable unit. Identified occupational exposure guidelines for applicable radionuclides are listed in the Table 6.4.1. No soil and sediment criteria have been identified.

TABLE 6.4.1

AIR AND WATER MPCS FOR OCCUPATIONAL EXPOSURES ${ }^{1}$ OF RADIONUCLIDES $(\mu \mathrm{Cl} / \mathrm{ml})$

\begin{tabular}{|c|c|c|c|c|}
\hline Radionuclide & Primary emission & Radiotoxicity ${ }^{2}$ & $(M P C) w^{3}$ & (MPC) $a^{4}$ \\
\hline 90 Strontium & beta & very high & $4 \times 10^{-6}$ & $3 \times 10^{-10}$ \\
\hline 137Cesium & beta; gamma & moderate & $4 \times 10^{-4}$ & $6 \times 10^{-8}$ \\
\hline 239Plutonium & alpha & very high & $10^{-4}$ & $2 \times 10^{-12}$ \\
\hline Tritium & beta & slight & 0.1 & $5 \times 10^{-6}$ \\
\hline Unidentified & alpha & - & $10^{-7}$ & $4 \times 10^{-13}$ \\
\hline Unidentified & bota & - & $10^{-7}$ & $4 \times 10^{-13}$ \\
\hline
\end{tabular}

From "Radiological Health Handbook", U.S. Department of Health, Education, and Welfare, Washington, D.C.

2 From "Safe Handling of Radionuclides", Safety Series No. 1, International Atomic Energy Agency, Vienna.

$3 \quad(M P C) w=$ Maximum Permissible Concentration in water except (MPCU)w for unidentified radionuclides.

4 (MPC)a = Maximum Permissible Concentration in air except (MPCU)a for unidentified radionuclides.

Modified from RFI/RI Work Plan for Tank 16 (1991). 


\subsection{EXPOSUREPATHWAYS}

Exposure pathways are those avenues by which contaminants have or may come in contact with receptors such as workers, the public, and the environment. These pathways identify real or potential hazard migration from contaminated/potentially contaminated media to identifiable receptors. The identified pathways for the media of concern (groundwater) described in section 3.0 assuming industrial/commercial land use are described in the following sections.

Wetlands and biota (florafauna) impacts will be addressed in future evaluations.

\subsection{GROUNDWATER}

The contaminated water table aquifer in the Tank 16 area is not used for potable purposes. This groundwater aquifer is monitored by SRS personnel resulting in potential exposure through dermal absorption. The potential of migration of contaminants into the lower aquifer (McBean) will be addressed in the implementation of the RFVRI Work Plan for Tank 16. The McBean aquifer flow rate is characteristically faster than the water table.

\subsection{SOIL}

Subsurface soils have been contaminated and may pose exposure to SRS workers during D\&D activities and subsurface maintenance in the H-Area Tank Farm through inhalation of particulates and direct external exposure of radionuclides. Subsurface soils also pose as a continuing source of contamiriation of the groundwater.

\subsection{SURFACE WATER}

No surface water contamination has been detected that is solely identifiable with the Tank 16 groundwater operable unit. (Tritium has been detected in Upper Three Runs Creek.)

\subsection{SEDIMENT}

No sediment contamination has been detected that is solely identifiable with the Tank 16 groundwater operable unit.

\section{$7.5 \quad$ AIR}

Exposure via air transport is dependent on the fate of soils at the Tank 16 operable unit as well as migration of groundwater as a primary transport means.

\subsection{STRUCTURES}

Tank Farm maintenance activities and future D\&D activities could result in further exposure of radionuclides to the environment (i.e., groundwater).

\subsection{SOLID WASTES}

Waste removal from Tank 16 was initiated in 1972 as a result of additional leakage. Only residual wastes were left in the tank and annulus areas. Any liquids remaining at the time of waste removal have solidified leaving only solid wastes within the tank and annulus areas. Subsequent remote observations of the Tank 16 primary and annulus have verified the solid nature of remaining tank waste. 
Approximately 75 gallons of water-insoluble waste containing 56,000 curies (Ci) of activity reniain in the tank primary (see Table 3.1). The insoluble waste is mainly ferrous oxalate. The activity in the tank primary is primarily $\mathrm{Sr}^{90}$.

An estimated 22,000 pounds of waste (natrodavyne and sand) containing 30,000 curies of activity remain in the tank annulus (see Table 3.1). The activity in the tank annulus is due primarily to $\mathrm{Cs}^{137}$.

Any additional activities to remove waste residuals could increase the potential exposure of radionuclides to the environment (i.e., groundwater).

\subsection{LIOUID WASTES}

No liquid wastes are present in Tank 16 or its annulus. Any liquids remaining at the time of waste removal have solidified leaving only solid wastes within the tank and annulus areas. Subsequent remote observations of the Tank 16 primary and annulus have verified the solid nature of remaining tank waste.

\subsection{SLUDGES}

Although initial Tank 16 wastes were characterized as sludge and supernatant, all sludges have solidified since the last waste removal in 1972. Subsequent remote observations of the Tank 16 primary and annulus have verified the solid nature of remaining tank waste. 


\subsection{RRELIMINARY REMEDIALACTION OBJECTIYES}

Preliminary remedial action objectives (RAOs) consist of medium/operable unit specific goals for protecting human health and the environment. These objectives are specific and do not limit the range of alternatives that may be developed. The preliminary RAOs specify the contaminants of concern and exposure limits for human health and environmental protection for each media of concern.

The human health based RAOs were developed using MCLs identified in Tables 6.1.1 and 6.1.2. for ingestion of water from the groundwater medium. In the absence of environmental standards and identifiable ARARs for determining environmental protection based RAOs, TBC occupational exposure guidelines (see Table 6.4.1) were used for the development of preliminary RAOs for dermal adsorption by workers of the groundwater medium.

Preliminary RAOs for the Tank 16 groundwater operable unit are described below. RAOs for the other media (soils, surface water, sediment, air, structures, solid wastes, liquid wastes, and sludges) will be evaluated as assessment of the Tank 16 source unit proceeds.

\section{GROUNDWATER MEDIUM}

- For Human Health

- Prevent dermal absorption of water having a total excess cancer risk for all contaminants of $10^{-6}$.

- Prevent ingestion of water having a total excess cancer risk for all contaminants of $10^{-6}$.

- Prevent ingestion of water having ${ }^{137} \mathrm{Cs}$ in excess of $2 \times 10^{-7} \mu \mathrm{Ci} / \mathrm{ml}$.

- Prevent ingestion of water having ${ }^{134} \mathrm{Cs}$ in excess of $8.13 \times 10^{-8} \mu \mathrm{Ci} / \mathrm{ml}$.

- Prevent ingestion of water having ${ }^{90} \mathrm{Sr}$ in excess of $8 \times 10^{-9} \mu \mathrm{CV} / \mathrm{ml}$.

- Prevent ingestion of water having adjusted gross alpha emitters (including Ra226/ excluding Rn \& U) which result in a total body or organ dose of $1.5 \times 10^{-5} \mu \mathrm{CV} / \mathrm{ml}$.

- Prevent ingestion of water having adjusted gross alpha emitters (excluding U, Ra226, Rn222) which result in a total body or organ dose of $1.5 \times 10^{-5} \mu \mathrm{Ci} / \mathrm{ml}$.

- Prevent ingestion of water having beta particle and photon emitters which result in a total body or organ dose of $4 \mathrm{mrem} / \mathrm{yr}$.

- Prevent ingestion of water having beta particle and photon emitters (excluding Ra228) which result in a total body nr organ dose of 4 mrem ede/yr.

No dermal exposure MCLs have been identified for radionuclides. Worker exposure standards that must be adhered to during remedial activities (occupational exposure levels) have been used to provide an RAO dermal exposure starting point for the evaluation of remedial alternatives.

- Prevent dermal exposure of water having ${ }^{137} \mathrm{Cs}$ in excess of $4 \times 10^{-4} \mu \mathrm{CV} / \mathrm{ml}$.

- Prevent dermal exposure of water having ${ }^{90} \mathrm{Sr}$ in excess of $4 \times 10^{-6} \mu \mathrm{Ci} / \mathrm{ml}$.

- Prevent dermal exposure of water having unidentified alpha in excess of $10^{-7} \mu \mathrm{Ci} / \mathrm{ml}$.

- Prevent dermal exposure of water having unidentified beta in excess of $10^{-7} \mu \mathrm{Ci} / \mathrm{ml}$.

- For Environmental Protection

RAOs that identify goals relating to the prevention of radionuclide contaminated groundwater migration to surface water, sediments, and soils and the prevention of continued radionuclide contamination of groundwater from source media which are primarily soil, structure, and solid waste will be determined in the ecological risk assessment. 


\subsection{RRELIMINARY GENERAL RESPONSE ACTIONS}

Preliminary general response actions (GRAs) describe medium specific actions (treatment, containment, excavation, extraction, disposal, institutional actions, and no action) which will satisfy the preliminary RAOs. An initial determination of areas or volumes of media which are applicable to GRAs is made. Only the groundwater medium was evaluated. The other media (soils, surface water, sediment, air, structures, solid wastes, liquid wastes, and sludges) will be evaluated as assessment of the Tank 16 source unit proceeds.

GROUNDWATER MEDIUM

- No Action/Institutional Controls

- No Action

- Access Control/Restrictions

- Monitoring

- Containment

- Constructed Barrier

- Recovery/Removal

Not Applicable

- Treatment

- Collection/Treatment/Discharge

- Insitu Treatment

- Disposal

Not Applicable 


\subsection{REMEDIAL TECHNOLOGY TYPES}

A range of remedial technologies (e.g. chemical/physical treatment, thermal destruction, isolation, prevention, stabilization, etc.) which provides for treatment, containment, and removal requirements of any contaminated media remaining at the operable unit are identified/developed which will satisfy the preliminary RAOs. Several broad technology types are identified for each preliminary GRA. Specific process options have been identified but are not thoroughly addressed in this report. The Remedial Action Assessment System (RAAS) Technology Information System (White et al., 1991), avallable reference material, SRS reports, and regulatory guidance were used as initial tools for the screening of remedial technologies for the Tank 16 groundwater operable unit. The following summarizes key technology types identified for the groundwater medium specific GRAs.

\section{GROUNDWATER MEDIUM}

- No Action/Institutional Controls - No Action

a) No Further Action

- Access Control/Restrictions

- Monitoring

a) Institutional controls through Site Use Permits

a) Establish monitoring program to observe contaminant migration

- Containment

- Constructed Barriers

a) Vertical barriers

- Slurry wall

- Grout curtain

- Sheet piling

b) Horizontal barriers

- Grout injection

- Capping

- Recovery/Removal

Not Applicable

- Treatment

- CollectionTreatment/Discharge

a) Groundwater collection/pumping

b) Physical treatment

- pH adjustment

- Filtering

c) Chemical treatment

- Ion exchange

- Insitu Treatment

- Reverse osmosis

a) Fixation

- Disposal

Not Applicable 


\subsection{REFERENCES}

11.1 Abel, M.D., Cook, J.R., 1987, "Tank 16 Decommissioning Demonstration: VGA Basic Data", DPSP-87-1219, E. I. duPont de Nemours and Company, Savannah River Plant, Alken, SC.

11.2 Comprehensive Environmental Response, Compensation and Liability Act of 1980 CERCLA (Superfund), PL 96-410, As amended by PL 97-216, July 18, 1982; PL 97-272, September 30, 1982; PL 98-45, July 12, 1983; and PL 99-499, October 17, 1986.

11.3 Davis, T. L., Tharin, D. W., Jones, D. W., and Lohr, D. R., 1977, "History of Waste Tank 16, 1959 through 1974", DPSPU-77-11-17, E. I. duPont de Nemours and Company, Savannah River Plant, Aiken, SC.

11.4 "Risk Assessment Guidance for Superfund: Volume 1 - Human Health Evaluation Manual (Part B, Development of Risk-based Preliminary Remediation Goals)", OSWER Directive 9285.7-01B, December 1991.

11.5 "Guidance for Conducting Remedial Investigations and Feasibility Studies under CERCLA Interim Final", EPA540/G-89/004, OSWER Directive 9355.3-01, October 1988.

11.6 "National Interim Primary Drinking Water Regulations", 1977, EPA-570/9-76-003.

11.7 "National Oil and Hazardous Substances Pollution Contingency Plan", 40 CFR 300, Final Rule, March 8, 1990.

11.8 "National Primary Drinking Water Regulations", 1991, 40 CFR (Code of Federal Regulations.

11.9 "National Primary Drinking Water Regulations; Radionuclides; Proposed Rule", July 18, 1991, U. S. Environmental Protection Agency, Federal Register.

11.10 Prendergast, J.T., 1982, "Decommissioning Alternatives for Waste Tank 16", DPST-82-456, E. I. duPont de Nemours and Company, Savannah River Plant, Aiken, SC.

11.11 Poe, W. L., Fenimore, J. W., Horton, J. H., Marine, I. W., and Prout, W. E., 1974, "Leakage From Waste Tank 16, Amount, Fate, and Impact", DP-1358, E. I. duPont de Nemours and Company, Savannah River Laboratory, Aiken, SC.

11.12 "RFI/RI Work Plan for Tank 16", WSRC-RP-90-497, February 25, 1991, Westinghouse Savannah River Company, Savannah River Site, Aiken, SC.

11.13 Thomas, C.J. to Morris, O.M., 1985, "Tank 16 Decommissioning Plan", DPSP-85-17-2, E. I. duPont de Nemours and Company, Savannah River Plant, Aiken, SC.

11.14 "Technological Approaches to the Cleanup of Radiologically Contaminated Superfund Sites", EPA 540/2-88/002, August, 1988.

11.15 "Technology Screening Guide for Treatment of CERCLA Soils and Sludges", EPA540/2-88/004, September 1988. 
11.16 "Water Pollution Control; National Primary Drinking Water Regulations;

Radionuclides (Proposed)", September 30, 1986, U. S. Environmental Protection Agency, Federal Register. 

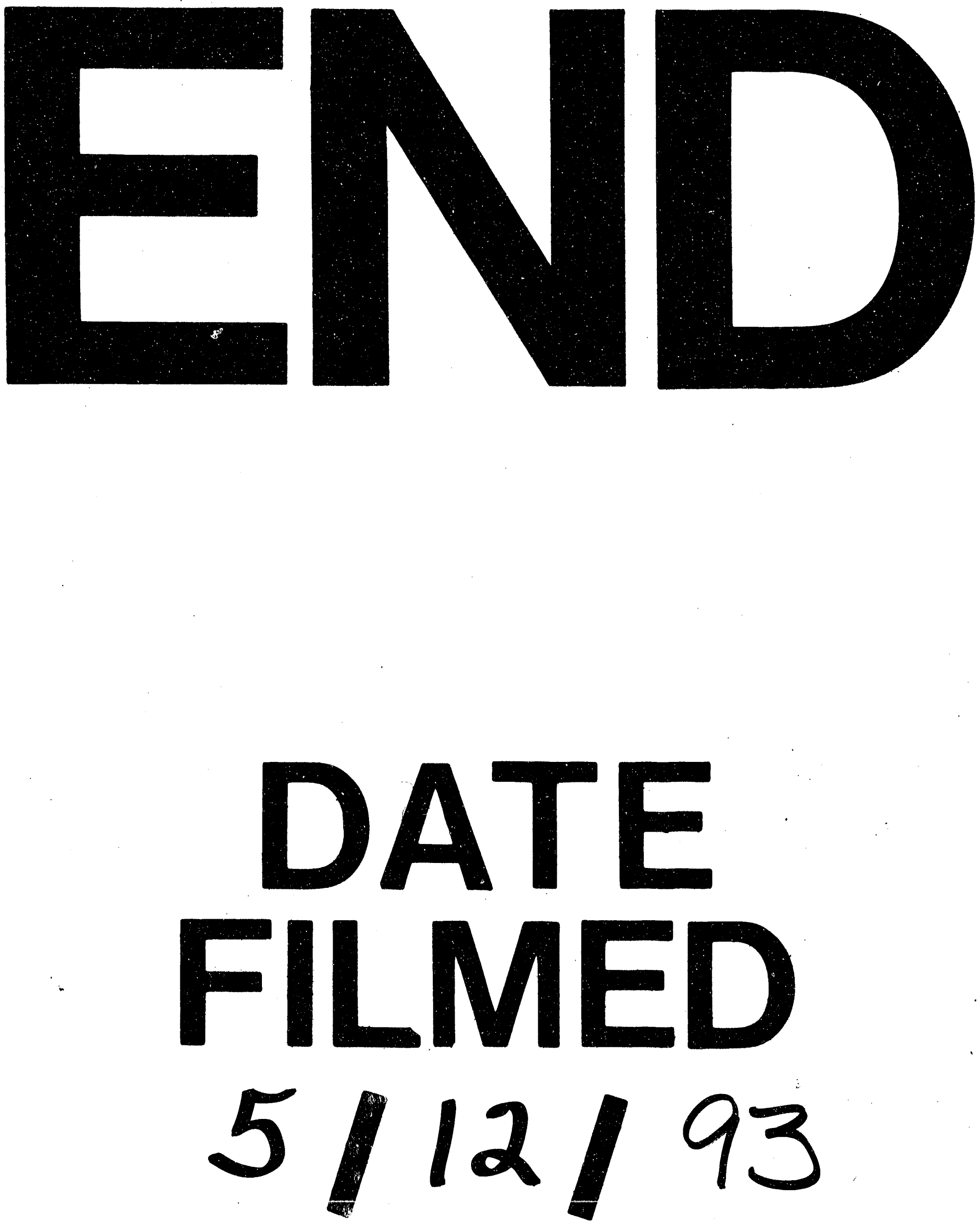
